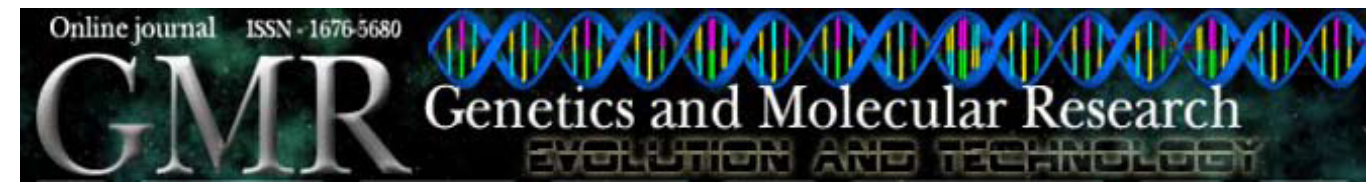

\title{
Hygienic behavior in the stingless bees Melipona beecheii and Scaptotrigona pectoralis (Hymenoptera: Meliponini)
}

\author{
L.M.Medina ${ }^{1,3}$, A.G. Hart ${ }^{2,3}$ and F.L.W. Ratnieks ${ }^{3}$ \\ ${ }^{1}$ Facultad de Medicina Veterinaria y Zootecnia, \\ Universidad Autónoma de Yucatán, Merida, Yucatan, Mexico \\ ${ }^{2}$ Department of Natural and Social Sciences, \\ University of Gloucestershire, Cheltenham, UK \\ ${ }^{3}$ Laboratory of Apiculture \& Social Insects, \\ Department of Animal and Plant Sciences, University of Sheffield, Sheffield, UK \\ Corresponding author: L.M. Medina \\ E-mail:mmedina@uady.mx
}

Genet. Mol. Res. 8 (2): 571-576 (2009)

Received December 12, 2008

Accepted January 26, 2009

Published May 19, 2009

\begin{abstract}
Hygienic behavior, a trait that may confer resistance to brood diseases in the honey bee Apis mellifera, was studied in two species of stingless bees in Mexico. Eight colonies each of Melipona beecheii and Scaptotrigona pectoralis were tested for hygienic behavior, the removal of dead or diseased brood, by freeze killing a comb of sealed cells containing pupae. Both species detected and removed dead brood. However, removal rates differed between species. In $M$. beecheii colonies, workers took 2-9 days to remove $100 \%$ of the dead brood $(4.4 \pm 2.0$ days, mean \pm SD), while $S$. pectoralis removed all dead brood in less than 3 days $(2.3 \pm 0.6$ days, mean $\pm \mathrm{SD}$ ). We conclude that hygienic behavior is not unique to A. mellifera, and is not solely an adaptation for the reuse of brood cells as occurs in honey bees but not stingless bees. Although stingless bees do not reuse brood cells, space is limited. The removal of dead brood may be necessary to allow new cells to be constructed in the same place.
\end{abstract}

Key words: Hygienic behavior; Melipona beecheii; Scaptotrigona pectoralis; Stingless bees; Meliponini 


\section{INTRODUCTION}

Hygienic behavior in honey bees (Apis mellifera) was initially studied in the USA with a view to increasing resistance to American foulbrood (AFB; Park, 1937), an important brood disease (Ratnieks, 1992; Spivak and Gilliam, 1998a,b; Hansen and Brodsgaard, 1999). American foulbrood is caused by the bacterium Paenibacillus larvae, which kills old larvae and young pupae shortly after the cell is capped with wax by adult worker bees. If not removed, a larva killed by $P$. larvae desiccates, forming a scale that contains billions of long-lived $P$. larvae spores, which may infect other larvae in the same colony or be spread to other colonies, by bees or beekeepers (Ratnieks, 1992; Hansen and Brodsgaard, 1999).

Early studies showed that colonies most resistant to AFB were those in which workers removed dead brood rapidly (reviewed by Spivak and Gilliam, 1998a). These socalled hygienic workers (aged 15-18 days; Arathi et al., 2000) detect, uncap and remove diseased or dead brood from their cells before $P$. larvae sporulates and becomes infective. Hygienic behavior, therefore, can prevent AFB from infecting other larvae within the colony, and provides a behavioral mechanism of disease resistance. It may also prevent female Varroa mites from breeding in brood cells, and also helps protect against chalk brood disease. It has been suggested that hygienic behavior is unique to honey bees (Arathi et al., 2000), in which it serves as an adaptation for the re-use of brood cells. Honey bee nests contain parallel vertical combs of hexagonal cells, which are used repeatedly both for food storage (nectar, honey and pollen) and for brood rearing. Consequently, dead brood must be removed to free up space for further brood or food storage, especially during nectar flows, when large amounts of food must be stored (Momot and Rothenbuhler, 1971).

In contrast to honey bees, stingless bees (Meliponini) have brood cells arranged in horizontal single-sided combs (e.g., Melipona) or in grape-like clusters (i.e., Frieseomelitta). Brood cells are mass provisioned shortly before oviposition, and are then capped within minutes of oviposition (Sakagami, 1982). The bees then develop without further contact with workers. In contrast, honey bee larvae are continuously provisioned, and the cell is only capped approximately nine days after oviposition, shortly before the larva begins pupation. Furthermore, brood cells are destroyed in stingless bees after adult emergence and new brood cells are constructed in the empty space (Sakagami, 1982). Food storage in stingless bees also differs from Apis. Stingless bees store nectar and pollen in egg-like wax pots similar to the storage pots found in bumblebees (Bombini; Michener, 1974). If hygienic behavior in honey bees is an adaptation for cell reuse, then the combination of brood cell destruction and separate food storage structures in stingless bees suggests that hygienic behavior should not have evolved in this group.

Hygienic behavior in A. mellifera has been widely studied, in part due to the economic importance of honey bees and because hygienic behavior is proposed to confer resistance to several brood diseases (reviewed by Spivak and Gilliam, 1998a,b). But whether hygienic behavior occurs in stingless bees has not been investigated. We examined whether hygienic behavior (the ability of workers to detect, uncap and remove dead brood from their cells) occurs in the stingless bee species, Melipona beecheii and Scaptotrigona pectoralis. 


\section{MATERIAL AND METHODS}

\section{Study site and study organisms}

The study was carried out at the Department of Apiculture, Autonomous University of Yucatan, Merida, Mexico, from April to June 2002.

Eight queenright colonies of $M$. beecheii were studied. Colonies were transferred from $\log$ hives into shallow observation hives consisting of a wooden box $(49 \times 19 \times 20 \mathrm{~cm})$ with a glass lid to allow observations. When the nest was not being observed, the glass was covered with a layer of polystyrene foam and wood to block out light and provide insulation.

At the beginning of the study, colonies had a queen, approximately 1200 adult workers, 6-8 horizontal brood combs and more than 35 honey and pollen storage pots surrounding the brood combs. The brood combs were in a chamber covered by an involucrum, made from a mixture of beeswax and tree resin, which separated the brood area from the rest of the nest. Colonies were kept in a meliponary shelter, with a roof but no side walls. Workers were allowed to forage freely, entering and exiting the nest box through a 10-mm hole located in one side.

Eight queenright colonies of $S$. pectoralis were also studied. Colonies were transferred from natural nest cavities (hollow tree trunks) collected in the wild into observation hives consisting of a wooden box $(39 \times 18 \times 17 \mathrm{~cm})$ with a transparent glass lid covered with polystyrene and wood.

At the beginning of the study, each $S$. pectoralis colony had a queen, approximately 1400 adult workers, 5-7 horizontal brood combs, and more than 40 honey and pollen storage pots. The brood chamber was again covered by an involucrum. Workers were allowed to forage freely, entering and exiting the nest through a 7-mm hole located in one side of the box.

The populations of these study colonies were similar to those that occur in nature.

\section{Assaying hygienic behavior - the frozen brood assay}

The frozen brood assay (FBA) was developed to quantify hygienic behavior in honey bee colonies without the need for using disease organisms (Jones and Rothenbuhler, 1964; Spivak and Downey, 1998). The FBA involves killing a section of brood by freezing (either with liquid nitrogen or by refrigeration) and returning the dead brood to the nest so that subsequent hygienic behavior, the removal of the freeze-killed brood, can be studied. We used FBA to study hygienic behavior in stingless bees. A brood comb containing mature pupae (eyes pink to purple) was removed from the brood chamber of each colony of each species and the number of brood cells was counted. To kill the pupae, the comb was placed in a freezer at $-5^{\circ} \mathrm{C}$ for $24 \mathrm{~h}$, and then returned to its original colony. The freezekilled brood layer was placed at the top of the brood chamber, after removing any obscuring layers of involucrum. During observations, only the polystyrene and wood covers were removed and the freeze-killed brood comb was observed through the glass lid to reduce nest disturbance. This allowed us to count the freeze-killed brood cells remaining in the nest and to record any hygienic behavior, such as the removal of dead brood and the subsequent destruction of the cell. The freeze-killed brood cells remaining on the comb layer were observed daily until all freeze-killed brood had been removed. Two hygienic behavior assays were carried out on each colony, with approximately 20 days between assays. 


\section{Statistical analysis}

A three-way analysis of variance (ANOVA) was used to assess the effect of colony, assay and species on the time taken to remove all dead brood (Zar, 1996).

\section{RESULTS}

Workers of both $M$. beecheii and S. pectoralis were able to detect, uncap and remove frozen brood from brood cells. However, the dead brood removal rate differed between species. Melipona beecheii workers removed 100\% of the frozen brood (108 \pm 26 and $92 \pm 13$ frozen brood cells in the first and second assays, respectively) in $4.4 \pm 2.0$ days (both assays and all colonies combined, mean $\pm \mathrm{SD}$, range 2-9 days), whereas $S$. pectoralis removed $100 \%$ of the dead brood ( $91 \pm 14$ and $89 \pm 17$ frozen brood in the first and second assays, respectively) in only 2.2 \pm 0.6 days (mean $\pm \mathrm{SD}$, range 1-3 days; Figure 1). The difference between the two species was highly significant $(\mathrm{F}=23.3, \mathrm{P}<0.0001)$. However, there were no significant differences among colonies within a species $(\mathrm{F}=1.6, \mathrm{P}=0.18)$ or between assays $(\mathrm{F}=0.02, \mathrm{P}=0.8)$.

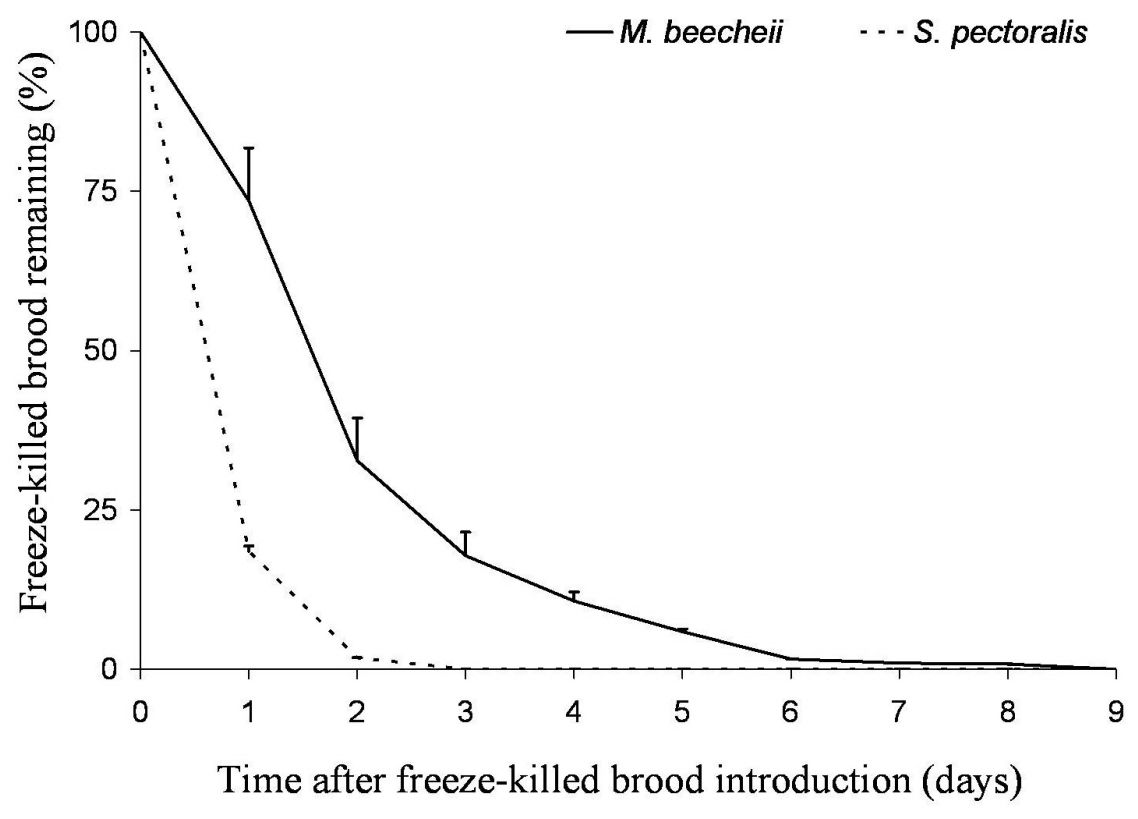

Figure 1. Removal rates of frozen brood (mean \pm SD) by the stingless bees Melipona beecheii (solid line) and Scaptotrigona pectoralis (dotted line) during two trials (mean data for eight colonies per species).

Workers of both species uncapped the cells containing dead brood and removed them, as in A. mellifera. However, dead brood was also removed through the walls of cells at the periphery of the comb. This behavior is not found in A. mellifera, as brood cells are reused rather than destroyed, and brood is not reared in the cells at the edges of combs. Dead brood removed by hygienic workers was deposited in each colony's internal waste dump and subsequently removed 
from the nest by other workers. In $M$. beecheii, workers uncapping and removing dead brood from cells were typically those individuals performing tasks in the brood chamber (20.7 \pm 5.7 days old; data not shown), which suggests that, as in honey bees (Arathi et al., 2000), hygienic workers are middle-aged workers that have not yet begun foraging.

\section{DISCUSSION}

The results clearly show that workers of the stingless bees $M$. beecheii and S. pectoralis can detect, uncap and remove dead brood from brood cells. This fulfils the criteria for hygienic behavior and shows that hygienic behavior is not unique to honey bees.

Hygienic behavior was found to be well developed and rapid in the two species studied. For example, workers of both species not only removed dead brood by uncapping cells (as in $A$. mellifera), but also by dragging brood through the walls of cells found in the periphery of the comb. In M. beecheii, in which it was possible to follow the fate of the dead brood removed from the cells, workers deposited dead brood and also waste from the destruction of old brood cells in the colony's waste dump, from where the material was taken by other workers for dumping outside the nest. In A. mellifera, hygienic workers removing dead brood from their cells drop them to the base of the nest cavity where other workers (undertakers) remove them from the nest (Arathi et al., 2000). Apis mellifera colonies do not have specific within-colony waste dumps. In $M$. beecheii, these dumps are also used to store feces (Medina LM, personal observations), whereas worker and drone honey bees defecate outside the nest.

Differences in the rates of brood removal in $M$. beecheii and $S$. pectoralis may relate to other differences in behavioral traits. For example, S. pectoralis, which is sometimes used in Yucatan for honey production, has very defensive behavior when compared with other local stingless bee species, including M. beecheii (Gonzalez and Medina, 1998). This may explain why S. pectoralis nests are rarely attacked by the phorid fly Pseudohypocera kerteszi, which is a serious pest in $M$. beecheii nests (Gonzalez JA, personal communication). The effective defensive behavior of $S$. pectoralis has also been noted during attacks of the Yucatecan cleptoparasitic (robber) stingless bee Lestrimelitta niitkib. Scaptotrigona pectoralis colonies defend their nests strongly and can attack and potentially destroy the nests of the attacking L. niitkib (Gonzalez and Medina, 1998). Stingless bees are diverse, with hundreds of species, and there are many differences in their behavior.

Although stingless bees can detect, uncap and remove dead brood from their cells, few stingless bee brood diseases have been reported (Nogueira-Neto, 1997; Schmid-Hempel, 1998). This is in contrast to the wide range of brood diseases in A. mellifera (Morse and Flottum, 1997). This may reflect a bias, with more studies conducted on honey bees because of their global economic importance. Or it may be that stingless bees really do have fewer diseases. Is this because they have effective mechanisms to deal with parasites and diseases not found in honey bees? For example, the destruction of used brood cells occurs in all stingless bee species, including those in which cells are arranged in clusters (e.g. Frieseomelitta) rather than in combs. Destroying old brood cells rather than repeatedly reusing them (as in A. mellifera) can potentially reduce disease transmission. In A. mellifera, new brood reared in cells in which the previous larva was killed by American foulbrood (with subsequent hygienic removal of dead brood) become infected in $8-19 \%$ of cases (Ratnieks, 1992). In addition to only being used once, brood cells in the stingless bees are mass-provisioned, and cell construction and food provisioning can be carried out by a very few workers (6-19 workers; van Veen, 2000). However, in A. mellifera, where brood is fed progressively, thousands of inspection visits and hundreds 
of feeding visits by worker bees are made to each brood cell (Winston, 1987). The high number of inspection and feeding visits in A. mellifera is likely to increase the transmission of pathogens among brood cells and individuals within a colony. Furthermore, because brood cells are massprovisioned, a stingless bee brood cell remains open for only a few minutes (about 6 min in $M$. beecheii; van Veen, 2000) after an egg is laid. However, A. mellifera worker brood cells remain open for around 8.5 days ( 3 days as an egg, 5.5 days as a larva; Winston, 1987), greatly increasing the opportunity for infection.

Hygienic behavior is suggested to be the principal resistance mechanism against brood disease in A. mellifera and it has been proposed that the reuse of cells was an important factor in the evolution of hygienic behavior. The existence of well-developed hygienic behavior in the honey bees' sister group, the stingless bees, suggests that cell reuse was not necessary for the initial evolution of hygienic behavior, although it may explain its maintenance in A. mellifera.

\section{ACKNOWLEDGMENTS} (UADY-44)

We thank H. Moo-Valle for his field support. Research supported by PROMEP

\section{REFERENCES}

Arathi HS, Burns I and Spivak M (2000). Ethology of hygienic behaviour in the honey bee Apis mellifera L. (Hymenoptera: Apidae): behavioural repertoire of hygienic bees. Ethology 106: 365-379.

Gonzales JAA and Medina LM (1998). La Respuesta Defensiva de Scaptotrigona pectoralis como un Contundente Escudo de Protección Contra las Incursiones de Lestrimellita niitkib Dirigidas a otras Especies de Abejas sin Aguijón. In: VI Congreso Ibero-Latinoamericano de Apicultura, Mérida, 171-173.

Hansen H and Brodsgaard CJ (1999). American foulbrood: a review of its biology, diagnosis and control. Bee World 80: 5-23.

Jones RL and Rothenbuhler WC (1964). Behaviour genetics of nest cleaning in honey bees. II. Response of two inbred lines to various amounts of cyanide-killed brood. Anim. Behav. 12: 584-588.

Michener CD (1974). The social behaviour of the bees: a comparative study. Harvard University Press, Cambridge.

Momot JP and Rothenbuhler WC (1971). Behaviour genetics of nest cleaning in honey bees. V. Interactions of age and genotype of bees, and nectar flow. J. Apic. Res. 10: 11-21.

Morse RA and Flottum K (1997). Honey Bee Pests, Predators, and Diseases. A.I. Root Company, Medina.

Nogueira-Neto P (1997). Vida e Criação de Abelhas Indígenas sem Ferrão. Editora Nogueirapis, São Paulo.

Park OW (1937). Testing for resistance to American foulbrood in honeybees. J. Econ. Entomol. 30: 504-512.

Ratnieks FLW (1992). American foulbrood: The spread and control of an important disease of the honey bee. Bee World 73: $177-191$

Sakagami SF (1982). Stingless Bee. In: Social Insects III (Hermann RH, ed.). Academic Press, New York, 361-423.

Schmid-Hempel P (1998). Parasites in Social Insects. Princeton University Press, Princeton.

Spivak M and Downey DL (1998). Field assays for hygienic behavior in honey bees (Hymenoptera: Apidae). J. Econ. Entomol. 91: 64-70.

Spivak M and Gilliam M (1998a). Hygienic behaviour of honey bees and its application for control of brood diseases and varroa. Part I. Hygienic behaviour and resistance to American foulbrood. Bee World 79: 124-134.

Spivak M and Gilliam M (1998b). Hygienic behaviour of honey bees and its application for control of brood diseases and varroa. Part II. Studies on hygienic behaviour since the Rothenbuhler era. Bee World 79: 169-186.

van Veen JW (2000). Cell provisioning and oviposition in Melipona beecheii (Apidae, Meliponinae), with a note on caste determination. Apidologie 31: 411-419.

Winston ML (1987). The Biology of the Honey Bee. Harvard University Press, Cambridge.

Zar JH (1996). Biostatistical Analysis. Prentice Hall Inc., New Jersey.

Genetics and Molecular Research 8 (2): 571-576 (2009) 